\title{
Painful adult scoliosis with kyphosant evolution and sagittal anterior trunk imbalance treated with physical therapy techniques: three
}

\section{case reports}

\author{
M Villagrasa*, E Pou, G Quera Salvá and M Rigo
}

Address: Institut E. Salvá. Vía Augusta 185. 08021 Barcelona, Spain

Email: M Villagrasa* - monikve78@hotmail.com

* Corresponding author

\author{
from 6th International Conference on Conservative Management of Spinal Deformities \\ Lyon, France. 21-23 May 2009 \\ Published: I4 December 2009 \\ Scoliosis 2009, 4(Suppl 2):O65 doi:I0.II86/I748-7|6|-4-S2-O65
}

This abstract is available from: http://www.scoliosisjournal.com/content/4/S2/O65

(c) 2009 Villagrasa et al; licensee BioMed Central Ltd.

\section{Purpose of the study}

The objective of this study is to show positive clinical changes after physical therapy in three patients diagnosed with painful adult scoliosis with kyphotic evolution.

\section{Background}

Painful adult scoliosis presenting kyphotic evolution combined with an anterior imbalance of the trunk is one of the most difficult clinical conditions in rehabilitation. Clinical changes during rehabilitation treatment (physical therapy) can be measured by using surface topography, although postural changes can produce measurement fluctuations, and interpretations should be made cautiously. This type of patient presents with considerable stiffness of the spine, and their kyphotic deformity used to be irreducible.

\section{Methods}

Three case reports.

\section{Patient I}

74 year old female at her first consultation. The patient had severe painful scoliosis (associated degenerative and osteoporosis changes), with a right thoracolumbar curve of $67^{\circ}$ and a kyphosis measurement of $69^{\circ}$ between T10 and L3. The treatment and observation period was 23 months.

\section{Patient 2}

50 year old female at her first consultation. The patient had adult painful scoliosis, with a right lumbar curve measuring $66^{\circ}$ with $>50^{\circ}$ axial rotation, rotatory listhesis at T11-T12 and L3-4-5, degenerative changes, and lumbar kyphosis. The treatment and observation period was 4 months.

\section{Patient 3}

50 year old female at her first consultation. The patient had junctional kyphosis caudal and cranial to Harrington instrumentation (T5-T12), a lumbar scoliosis curve measuring $55^{\circ}$, hyper-rotated, rotatory listhesis at L3-4, and degenerative changes. The treatment and observation period was 7 months.

\section{Results \\ Patient I}

Improved to no pain. Lateral deviation and rotation decreased from $34 \mathrm{~mm}$ and $16^{\circ}$ to $26 \mathrm{~mm}$ and $12^{\circ}$. Frontal plane imbalance (T1-CSL) decreased from $27 \mathrm{~mm}$ to $12 \mathrm{~mm}$. The patient experienced significant correction of the anterior trunk imbalance and reduction of the kyphotic angle VP-ITL from $66^{\circ}$ to $58^{\circ}$.

\section{Patient 2}

Improved to no pain. Lateral deviation and rotation decreased from $30 \mathrm{~mm}$ and $16^{\circ}$ to $19 \mathrm{~mm}$ and $10^{\circ}$. Frontal plane imbalance decreased from $46 \mathrm{~mm}$ to $21 \mathrm{~mm}$ (T1- 
CSL). The patient experienced significant correction of the lumbar kyphosis and the anterior trunk imbalance.

\section{Patient 3}

Improved to no pain. Lateral deviation and rotation decreased from $27 \mathrm{~mm}$ and $15.5^{\circ}$ to $22.3 \mathrm{~mm}$ and $14^{\circ}$. Kyphotic angle VP-ITL decreased from $65^{\circ}$ to $56^{\circ}$ with a highly noticeable correction of the junctional kyphosis.

\section{Conclusion}

Painful adult scoliosis with kyphotic evolution and sagittal anterior trunk imbalance can be managed using physical therapy techniques.

Publish with Bio Med Central and every scientist can read your work free of charge

"BioMed Central will be the most significant development for disseminating the results of biomedical research in our lifetime. " Sir Paul Nurse, Cancer Research UK

Your research papers will be:

- available free of charge to the entire biomedical community

- peer reviewed and published immediately upon acceptance

- cited in PubMed and archived on PubMed Central

- yours - you keep the copyright 